\title{
PENGEMBANGAN MULTIMEDIA PEMBELAJARAN PATISERI UNTUK SISWA TINGKAT XI SMK
}

\author{
Tri Sunarmi \\ SMK N 4 Surakarta \\ trisunarmi@ymail.com \\ Amat Jaedun \\ Universitas Negeri Yogyakarta \\ a jaedun@yahoo.com
}

\begin{abstract}
Abstrak
Penelitian ini bertujuan untuk: 1) mengembangkan multimedia pembelajaran patiseri pada standar kompetensi mengolah kue pastry kontinental untuk siswa tingkat XI SMK yang layak dari aspek pembelajaran, materi, dan media; 2) mengetahui keefektifan multimedia pembelajaran patiseri yang dikembangan terhadap penguasaan kompetensi belajar mengolah kue pastry kontinental dilihat dari peningkatan skor tes hasil belajar. Jenis penelitian ini adalah penelitian dan pengembangan. Subyek penelitian adalah 36 siswa, untuk uji coba kelompok kecil dan uji coba lapangan. Validasi produk dilakukan oleh ahli materi dan ahli media. Selanjutnya data dianalisis dengan teknik analisis deskriptif.Hasil penilaian ahli materi dan ahli media menunjukkan bahwa kualitas multimedia "baik". Penilaian siswa pada uji coba lapangan mengenai kualitas multimedia dari aspek pembelajaran, aspek materi dan aspek media "sangat baik", dengan rerata skor dari ketiga aspek 4,49. Hasil pretes menunjukkan rerata sebesar 63,15 sedangkan rerata pada posttes sebesar 89,07. N-gain sebesar 0,72 termasuk kategori "tinggi”. Kesimpulannya: multimedia pembelajaran patiseri hasil pengembangan layak dignakan untuk media pembelajaran dan efektif untuk meningkatkan hasil belajar siswa.
\end{abstract}

Kata Kunci: multimedia pembelajaran patiseri

\section{DEVELOPING PATISSERIE TEACHING MULTIMEDIA FOR GRADE XI STUDENTS OF SMK}

\begin{abstract}
The research aims to: 1) develop the patisserie teaching multimedia at the standard competency for continental pastry for eleventh grade vocational students in patisserie program which is appropriate in terms of teaching aspect, material aspect, and media aspet; 2) reveal the effectiveness of the developed patisserie teaching multimedia at the standard competency forcontinental pastry, which is seen from the increase in the learning achievement test score. This research is a research and development. The subjects of the research are 36 students. The students are devided into two groups: small group trials and field trials. The data were analyzed by using the discriptive technique. The results of the product validation from the material expert and media expert show that the quality of the developed patisserie teaching multimedia is "good". The assessment of the students on the field trial of the quality of the multimedia from the teaching aspect, material aspect and media aspect get the score "very good". This shows that the quality of the developed patisserie teaching multimedia is in a "very good" category. The average score from the three aspects is 4.49 and it can be used as a patisserie teaching multimedia. The students' average score from the pretest is 63.25 while from the posttest is 89.07. Based on the pretest and posttest scores the n-gain is 0.72 , and it is included in a "high category". Therefore the patisserie teaching multimedia is effective to improve the students'learning achievement.
\end{abstract}

Keywords: patisserie teaching multimedia 


\section{PENDAHULUAN}

Undang-undang Sistem Pendidikan Nasional (UUSPN) pasal 3 dan penjelasan pasal 15 tentang pendidikan kejuruan menyebutkan bahwa, pendidikan kejuruan merupakan pendidikan menengah yang menyiapkan siswa atau peserta didik terutama untuk bekerja pada bidang tertentu. Sementara tujuan pendidikan SMK adalah meningkatkan kecerdasan, pengetahuan, kepribadian, akhlak mulia serta ketrampilan hidup mandiri dan mengikuti pendidikan yang lebih lanjut sesuai dengan kejuruannya. Hal ini terkait dengan salah satu tuntutan pengembangan KTSP, bahwa konsep pembelajaran harus dibuat fleksibel, mengingat perubahan teknologi selalu berubah seiring denghan perkembangan jaman.

Dalam KTSP siswa dikehendaki memiliki kompetensi dasar yang meliputi ranah pengetahuan (knowledge /kognitif), sikap (attitude/afektif) dan ketrampilan (skill/ psikomotor). Untuk menyiapkan itu semua, guru memiliki peran yang sangat penting. Guru sebagai pengajar harus berusaha agar materi pembelajaran yang disampaikan mampu diserap dan dimengerti oleh peserta didik. Pelaksanaan proses pembelajaran melibatkan beberapa komponen yang saling menunjang antara lain tujuan, materi, guru, metode, media, siswa, lingkungan dan evaluasi (Sukardjo, 2010, p. 9). Masing-masing komponen tersebut membentuk sebuah sistem yang mendukung tercapainya tujuan bersama yakni siswa yang berhasil dan lulusan yang berhasil.

Salah satu usaha untuk memudahkan peserta didik menerima materi ajar perlu diusahakan agar peserta didik dalam belajar menggunakan sebanyak mungkin alat indera yang dimiliki. Menurut Edgar Dale dalam Arsyad (2006, p. 9) pengalaman belajar seseorang 75\% diperoleh dari mata, 13\% melalui telinga dan selebihnya $12 \%$ melalui indera yang lain, sedangkan Baugh dalam Arsyad, (2006,p. 9) mengemukakan bahwa $90 \%$ hasil belajar seseorang diperoleh dari penglihatan, hanya $5 \%$ diperoleh dari pendengaran, dan 5\% melalui indera yang lain. Untuk itu media menjadi penting sekali untuk merangsang kegiatan belajar siswa, terutama media yang dapat mengoptimalkan seluruh indera manusia.
Lebih lanjut dijelaskan oleh Miarso (2004, p. 458) kegunaan media dalam pembelajaran adalah untuk memberikan rangsangan yang bervariasi kepada otak sehingga otak dapat berfungsi secara optimal. Media juga berguna untuk mengatasi keterbatasan pengalaman yang dimiliki siswa, dapat melampaui batas ruang kelas, banyak obyek yang tidak mungkin dibawa ke ruang kelas karena: objek terlalu besar, terlalu kecil, gerakan yang terlalu lambat, gerakan yang terlalu cepat untuk diamati, obyek yang terlalu kompleks, suara yang terlalu halus, dan rintangan berkenaan dengan musim atau cuaca. Selain itu media memungkinkan adanya interaksi langsung siswa dengan lingkungan, menghasilkan keseragaman pengamatan, membangkitkan minat dan keinginan baru, membangkitkan motivasi untuk belajar, memberikan pengalaman yang menyeluruh.

Kemajuan di bidang teknologi dan informasi memungkinkan untuk menghadirkan sebuah media berbasis teknologi informatika untuk membuat media yang dapat dengan mudah membantu siswa mempelajari semua kompetensi yang disampaikan oleh guru dengan jauh lebih mudah. Sehingga media pembelajaran tersebut sangat dirasa perlu agar siswa lebih mudah mencapai kompetensi yang diharapkan. Hal ini sekaligus untuk menjawab tantangan karena siswa SMK dituntut kompeten dibidang tertentu untuk dapat terserap di dunia kerja.

Perkembangan teknologi informasi yang begitu pesat ternyata berdampak luas hingga ke perkembangan pada media pembelajaran. Makin pesatnya perkembangan ilmu dan teknologi, guru selaku pendidik sekaligus sosok yang diharapkan mampu menjadi agent of change tidak boleh ketinggalan dalam teknologi pembelajaran. Dinamika ini menuntut guru selalu mampu mengembangkan dan menyajikan materi pelajaran yang aktual dengan menggunakan berbagai pendekatan, metode, media, dan teknologi pembelajaran yang terkini, agar guru mampu menyelenggarakan pembelajaran yang berhasil mengantarkan peserta didik memasuki dunia kehidupan sesuai dengan kebutuhan dan tantangn pada jamannya.

Guru harus menguasai berbagai metode dan model pembelajaran juga harus mampu 
menentukan media yang tepat sesuai karakter siswa dan mata pelajaran, terutama media berbasis IT. Selama ini Pembelajaran praktik di SMK N 4 Surakarta masih menggunakan metode konvensional yaitu metode demontrasi dan praktik dengan media job sheet dengan gambar diam, belum mengoptimalkan penggunaan media berbasis IT yang lebih variatif. Belum dioptimalkannya penggunaan media dalam pembelajaran praktik, menyebabkan kemampuan siswa dalam praktik kususnya pada praktik kompetensi kejuruan Standart Kompetensi Mengolah Kue Pastry Kontinental belum optimal baik secara teori maupun praktik.

Pemanfaatan multimedia pembelajaran menurut banyak ahli dapat menjadi alat bantu dalam menyampaikan pesan dalam proses pembelajaran. Multimedia juga dapat menjembatani perbedaan kompetansi dan gaya belajar siswa karena dapat mengaktifkan semua indera yang dimiliki siwa, sehingga belajar akan lebih optimal, dan menyenangkan. Pada kenyataannya pelaksanaan pembelajaran di SMKN 4 surakarta masih belum memanfaatkan media secara bervariasi, guru mengajar masih monoton, belum memanfaatkan kemajuan perkembangan teknologi informasi dan komunikasi, terutama pemanfaatan multimedia pembelajaran yang menunjang pembelajaran teori maupun praktik kejuruan. Hal ini disebabkan oleh banyak faktor diantaranya, belum dimilikinya multimedia pembelajaran kejuruan berbasis IT, sedangkan sarana dan prasarana untuk pembelajaran dengan menggunakan IT sudah tersedia.

Standar Kompetensi Mengolah Kue Pastry Kontinental terdiri dari tujuh Kompetensi dasar (KD) diantaranya: (1) Menguraikan pengertian kue kontinental; (2) Membuat bahan pengisi dan bahan penutup kue dari butter cream, royal icing dan coklat; (3) Membuat cake, gateaux, dan torten; (4) Membuat produk kue patiseri dari adonan cair; (5) Membuat produk kue patiseri dari adonan padat; (5) Menggunakan peralatan untuk pengolahan kue continental; (7) Menata dan menyajikan aneka kue pastry kontinental. Dalam pembelajaran SK-KD ini guru belum belum ada yang menggunakan multimedian pembelajaran. Sehingga dapat dikatakan belum di manfaatkan media pembelajaran secara optimal menyebabkan hasil belajar secara teori maupun praktik kompetensi ini belum maksimal.

Berdasarkan analisis kebutuhan siswa di lapangan menunjukkan bahwa menurut sebagian besar siswa, kompetensi Mengolah Kue Pastry Kontinental masih sesuatu yang awam karena jarang diterapkan dalam kehidupan sehari-hari, sehingga kompetensi ini memerlukan media yang lebih tepat untuk memudahkan siswa dalam menguasai kompetensi ini dengan baik.

Di SMKN 4 Surakarta telah memiliki sejumlah CD yang menayangkan tentang pembuatan berbagai produk patiseri serta cara membuat hiasan produk patiseri, namun CD ini belum memenuhi kriteria untuk dijadikan sebagai media pembelajaran, dan tidak bersifat interaktif.

Belum tersedianya media pembelajaran yang inovatif, masih rendahnya nilai kompetensi Mengolah Kue Pastry Kontinental dibanding kompetensi kejuruan yang lain, untuk mengoptimalkan pemanfaatan sarana pembelajaran yang tersedia di sekolah, serta untuk menjawab tantangan perkembangan teknologi pembelajaran yang makin dinamis tersebut maka guru sekaligus peneliti akan mencoba mengembangkan multimedia pembelajaran interaktif untuk pembelajaran kelas patiseri, standart kompetensi Mengolah Kue Pastry Kontinental pada kompetensi dasar Membuat bahan pengisi dan bahan penutup kue dari butter cream, royal icing dan coklat. Karena multimedia pembalajaran interaktif ini memiliki kelebihan dapat diputar ulang di bagian yang siswa belum begitu faham, juga dapat digunakan untuk belajar mandiri artinya untuk media belajar diluar jam efektif. Dengan demikian, penggunakan multimedia pembelajaran interaktif ini diharapkan akan membuat pembelajaran lebih menarik, dan lebih menyenangkan sehingga hasil belajar Mengolah Kue Pastry Kontinental akan lebih baik.

Permasalahan dalam penelitian ini dapat dirumuskan sebagai berikut: (1) Bagaimana langkah-langkah sistematis dalam mengembangkan multimedia pembelajaran 
Patiseri Standar Kompetensi Mengolah Kue Pastry Kontinental untuk siswa tingkat XI SMK yang layak dari aspek pembelajaran, aspek materi dan aspek media. (2) Bagaimana kualitas multimedia pembelajaran patiseri Standar Kompetensi Mengolah Kue Pastry Kontinental untuk siswa tingkat XI SMK dari aspek pembelajaran, aspek materi dan aspek media. (3) Bagaimana keefektivan multimedia pembelajaran patiseri hasil pengembangan terhadap penguasaan hasil belajar pada Standar Kompetensi Mengolah Kue Pastry Kontinental

\section{METODE PENELITIAN}

\section{Model Pengembangan}

Jenis penelitian ini adalah penelitian dan pengembangan atau R\&D (research and development). Penelitian dan pengembangan adalah penelitian yang berorientasi untuk menghasilkan atau mengembangkan dan memvalidasi sebuah produk, sebagaimana yang dikemukakan oleh Borg \& Gall (2003, p. 569), bahwa penelitian pendidikan dan pengembangan adalah suatu proses yang digunakan untuk mengembangkan dan memvalidasi produk-produk yang digunakan dalam pendidikan. Dalam penelitian ini penulis mengembangkan dan memvalidasi media pembelajaran berupa multimedia pembelajaran patiseri untuk siswa tingkat XI SMK.

\section{Desain Uji Coba}

\section{Uji Coba Ahli Materi dan Ahli Media}

Sebelum di ujicobakan kepada siswa, produk yang telah dikembangkan terlebih dahulu divalidasi oleh ahli materi dan ahli media. Validasi ahli materi dan ahli media ini sangat penting untuk mendapatkan jaminan bahwa produk awal yang dikembangkan layak diujicobakan kepada siswa. Selain itu juga untuk mengantisipasi kesalahan dan kekurangan materi. Bantuan ahli sesuai bidangnya berupa penilaian, saran, komentar sangat diperlukan untuk perbaikan produk multimedia pembelajaran yang dikembangkan.

Pada tahap ini ali materi memberikan penilaian terhadap produk terkait aspek pembelajaran, isi atau materi, sedangkan ahli media memberikan penilaian terhada produk dari aspek tampilan, aspek penyajian, dan aspek pemrograman. Berdasarkan penilaian ahli materi dan ahli media ini dilakukan revisi sesuai saran. Setelah produk dinyatakan layak oleh ahli materi dan ahli media, selanjutnya dilakukan uji coba kepada siswa melalui uji coba kelompok kecil (small group evaluation) dan uji coba lapangan (field trial evaluation).

\section{Uji Coba Kelompok Kecil}

Tujuan dilakukan uji coba kelompok kecil (small group evaluation) adalah untuk mendapatkan bukti-bukti empiris tentang kelayakan produk awal secara terbatas. Uji coba dilakukan secara terpisah kepada sejumlah sembilan siswa diambil secara acak dengan kriteria, tiga siswa dari kelompok atas tiga siswa dari kelompok menengah dan tiga siswa dari kelompok bawah. Semua data yang diperoleh pada tahap ini berupa penilaian, komentar, dan saran disusun dan dianalisis untuk merevisi produk yang dikembangkan.

\section{Uji Coba Lapangan}

Tujuan dilakukan uji coba lapangan adalah untuk mendapatkan bukti-bukti empiris mengenai kelayakan produk yang dihasilkan dari sudut pandang siswa dari aspek pembelajaran, aspek materi, dan aspek media. Dalamuji coba lapangan ini sekaligus dilakukan pretest dan postest. Pretest dan posttest ini bertujuan untuk mengetahui multimedia pembelajaran patiseri yang dikembangkan benar-benar layak sebagai media pembelajaran dan memiliki efektivitas terhadap hasil belajar jika digunakan dalam seting lingkungan pembelajaran yang sebenarnya.

\section{Prosedur Pengembangan}

Prosedur pengembangan yang dipakai dalam penelitian ini adalah prosedur pengembangan yang diadaptasi dari Borg \& Gall (2003, p. 568) dan Dick \& Cerey (2005, p.1). Prosedur penelitian dan pengembangan multimedia pembelajaran patiseri ini meliputi lima tahapan pokok yaitu: (1) analisis kebutuhan, (2) tahapan perencanaan pengembangan produk, (3) tahapan pengembangan produk, (4) tahapan evaluasi produk dan, (5) produk akhir. 
Tabel 1. Pedoman Konversi Data Kuantitatif ke Data Kualitatif dengan Skala Lima

\begin{tabular}{llcc}
\hline \multirow{2}{*}{ Nilai } & Kriteria & \multicolumn{2}{c}{ Skor } \\
\cline { 2 - 4 } & & $\mathrm{X}>\overline{\mathrm{x}}_{1}+1,00 \mathrm{SBi}$ & Prosentase \\
\hline A & Sangat Baik & $\overline{\mathrm{x}}_{1}+0,60 \mathrm{SBi}<\mathrm{X} \leq \overline{\mathrm{x}}_{1}+1,80 \mathrm{SBi}$ & $3,40<\mathrm{X} \leq 4,21$ \\
$\mathrm{~B}$ & Baik & $\overline{\mathrm{x}}_{1}-0,60 \mathrm{SBi}<\mathrm{X} \leq \overline{\mathrm{x}}_{1}+0,60 \mathrm{SBi}$ & $2,60<\mathrm{X} \leq 3,40$ \\
C & Cukup & $\overline{\mathrm{x}}_{1}-1,80 \mathrm{SBi}<\mathrm{X} \leq \overline{\mathrm{x}}_{1}-0,60 \mathrm{Sbi}$ & $1,79<\mathrm{X} \leq 2,60$ \\
$\mathrm{D}$ & Kurang & $\mathrm{X} \leq \overline{\mathrm{x}}_{1}-1,80 \mathrm{SBi}$ & $\mathrm{X} \leq 1,79$ \\
$\mathrm{E}$ & Sangat Kurang & &
\end{tabular}

\section{Keterangan:}

Rerata Skor ideal $\left(\overline{\mathrm{x}}_{1}\right)$ :

$\frac{1}{2}$ ( skor maksimal ideal + skor minimal ideal)

\section{Subyek Uji Coba}

Subyek uji coba yang dilibatkan dalam penelitian ini direncanakan terdiri dari: 1 orang ahli materi, 1 orang ahli media, dan seluruh siswa tingkat XI Patiseri SMKN 4 Surakarta sejumlah satu kelas yang terdiri dari 36 siswa. Sejumlah 36 siswa tersebut adalah siswa yang belum pernah mendapatkan materi dari standar kompetensi mengolah kue pastry kontinental. Berdasarkan kurikulum KTSP yang mengacu pada spektrum, standar kompetensi mengolah kue pastry kontinental di berikan pada siswa tingkat XI semester genap. Dari sejumlah 36 siswa tersebut akan dilibatkan 9 orang siswa dilibatkan dalam uji coba kelompok kecil, sedangkan sisanya sejumlah 27 siswa dilibatkan dalam uji coba lapangan.

\section{Teknik analisis Data}

Data kualitatif yang berupa kritik dan saran dari ahli materi, ahli media dan siswa pada saat ujicoba, dihimpun dan sisarikan sebagai pedomam untuk melakukan revisi multimedia yang dikembangkan

Sedangkan data kuantitatif yang diperoleh dari hasi penilaian ahli materi, ahli media dan siswa dianalisis menggunakan statistik deskriptif kualitatif. Selanjutnya data dikonversikan menjadi data kualitatif skala
Simpangan baku skor ideal (Sbi) :

$\frac{1}{6}$ ( skor maksimal ideal - skor minimal ideal )

$\mathrm{X}$ ideal : Skor empiris

5 dengan menggunakan acuan konversi dari Sukardjo (2010, p. 101) seperti pada tabel 1.

Dalam penelitian ini ditetapkan nilai kelayakan produk multimedia pembelajaran patiseri sebagai media pembelajaran standart kompetensi Mengolah kue pastry kontinental kompetensi dasar Membuat bahan pengisi dan bahan penutup kue dari butter cream, royal icing dan coklat kompetensi keahlian patiseri SMK minimal adalah "B", dengan kategori "Baik", sebagai hasil penilaian dari ahli media, ahli materi dan siswa. Jika hasil penilaian akhir skor keseluruhan dari ahli materi, ahli media dan siswa dengan nilai minimal "B"(Baik) maka produk hasil pengembangan tersebut sudah dianggap layak digunakan sebagai media belajar. Untuk mencari skor rata-rata (rerata skor) dalam memberikan penilaian terhadap produk yang telah dikembangkan digunakan rumus:

$$
\overline{\mathrm{X}}_{1}=\frac{\sum \mathrm{x}}{\mathrm{n}}
$$

\section{Keterangan :}

$$
\begin{array}{ll}
\overline{\mathrm{X}}_{1} \mathrm{x} & : \text { skor rata-rata } \\
\mathrm{n} & : \text { jumlah skor } \\
& : \text { jumlah responden }
\end{array}
$$


Selanjutnya untuk mengetahui efektivitas produk multimedia pembelajaran patiseri dapat diketahui penilaian hasil belajar kognitif atau tingkat penguasaan materi standart kompetensi mengolah kue pastry kontinental yang diwujudkan dalam skor tes hasil belajar sebelum dan setelah menggunakan multimedia hasil pengembangan. Data pretest dan posttes hasil belajar siswa dianalisis dengan membandingkan skor pretest dan skor posttest. Peningkatan yang terjadi dari sebelum kegiatan pembelajaran dengan menggunakan produk multimedia pembelajaran dan sesudah pembelajaran menggunakan produkmultimedia pembelajaran diperhitungkan dengan rumus ( $N$-Gain) yang ditentukan berdasarkan ratarata gain skor. Yang dinormalisasi (g) yaitu perbandingan dari skor gain. Skor gain yaitu skor gain yang diperoleh siswa saat pretest dan posttest. Sedangkan skor gain maksimum yaitu skor gain tertinggi yang diperoleh siswa. Ratarata gain yang dinormalisasi (N-Gain) (Hake, 1998:2) dinyatakan oleh persamaan berikut:

$$
\mathrm{g}=\frac{\mathrm{S}_{\text {post }}-\mathrm{S}_{\text {pre }}}{\mathrm{S}_{\text {Maks }}-\mathrm{S}_{\text {pre }}}
$$

\section{Keterangan:}

S-post : Skor Posttes

S-Pre : Skor Pretest

S-Maks : Skor maksimal

Nilai ini selanjutnya diinterpretasikan ke dalam tabel klasifikasi nilai Gain (Hake, 1998, p. 3) sebagai berikut:

Tabel 2. Interpretasi Nilai Gain

\begin{tabular}{lc}
\hline Nilai $($ g) & Klasifikasi \\
\hline (N-gain $) \geq 0,7$ & Tinggi \\
$0,7>(\mathrm{N}$-gain $) \geq 0,3$ & Sedang \\
$(\mathrm{N}$-gain $)<0,3$ & Rendah \\
\hline
\end{tabular}

\section{HASIL PENELITIAN DAN PEMBAHASAN}

\section{Analisis kebutuhan}

\section{Studi lapangan}

Multimedia pembelajaran patiseri dikembangkan berdasarkan analisis kebutuhan di lapangan yang menunjukkan bahwa: (1) materi standar kompetensi Mengolah Kue Pastry kontinental merupakan materi produktif kejuruan patiseri yang dianggap sulit untuk dikuasai siswa; (2) siswa menginginkan materi Mengolah kue pastry kontinental disajikan dengan media belajar yang lebih bervariasi; (3) belum dimilikinya multimedia pembelajaran patiseri, sehingga siswa belum pernah menggunakan multimedia ini sebagai media belajar; (4) banyak siswa yang telah memiliki laptop, dan sarana pembelajaran di sekolah dengan berbantuan komputer, tersedia LCD untuk tiap ruang dengan sangat memadai sehingga multimedia pembelajaran sangat memungkinkan digunakan untuk pembelajaran secara individual; (5) belajar dengan multimedia pembelajaran interaktif lebih menarik dan lebih memudahkan siswa untuk belejar mandiri.

Hasil analisis kebutuhan yang dilakukan melalui diskusi dengan guru pengajar patiseri adalah: (1) hasil belajar siswa pada standar kompetensi mengolah kue pastry kontinental, baik secara teori maupun praktik belum sesuai yang diharapkan; (2) multimedia pembelajaran patiseri dapat dijadikan alternatif media yang tepat untuk membantu siswa dalam memahami materi baik secara kognitif maupun psikomotor.

\section{Studi Pustaka}

Studi pustaka dilakukan untuk mengetahui informasi tentang manfaat dan keuntungan dari penggunaan multmedia pembelajaran interaktif.

\section{Perencanaan Pengembangan produk (Design)}

Perencanaan pengembangan produk multimedia pembelajaran patiseri dilakukan dilakukan melalui tahapan sebagai berikut:

\section{Menetapkan Standar Kompetensi.}

Standar Kompetensi yang dirumuskan sesuai yang tertulis dalam Peraturan mentei Pendidikan Nasional (permendiknas) RI Nomor 22 tahun 2006 tentang Standar Isi SKKD Sekolah Menengah Kejuruan (SMK) kelompok Produktif yang mengacu pada Standart Kompetensi yang berlaku di dunia kerja,Pedoman penyusunan Kurikulum Tingkat Satuan Pendidikan (KTSP) juga Spektrum 
Keahlian Pendidikan Menenghah Kejuruan. Standart Kompetensi yang dimediakan adalah Standart Kompetensi: Mengolah Kue Pastry Kontinental.

\section{Menetapkan Kompetensi Dasar}

Perumusan Kompetensi Dasar yang ditetapkan dalam penelitian dan pengembangan ini sesuai dengan yang tertulis dalam Peraturan mentei Pendidikan Nasional (permendiknas) RI Nomor 22 tahun 2006 tentang Standar Isi SK-KD Sekolah Menengah Kejuruan (SMK) kelompok Produktif yang mengacu pada Standart Kompetensi yang berlaku di dunia kerja, Pedoman Penyusunan Kurikulum Tingkat Satuan Pendidikan (KTSP) juga Spectrum Keahlian Pendidikan Menenghah Kejuruan. Kompetensi dasar dalam penelitian dan pengembangan ini adalah: Membuat bahan pengisi dan bahan penutup kue dari butter cream, royal icing dan coklat.

\section{Menetapkan Indikator}

Perumusan indikator yang dalam penelitian dan pengembangan ini sesuai dengan silabus yang disusun oleh tim MGMP SMK Negeri 4 Surakarta.

\section{Menyusun Strategi Pembelajaran}

Menyusun strategi pembelajaran dengan menyusun silabus dan rencana pelaksanaan pemelajaran (RPP).

\section{Mengembangkan Materi Pembelajaran}

Dalam mengembangkan materi pembelajaran mengacu pada silabus yang disusun oleh tim MGMP SMK Negeri 4 Surakarta , dengan menggunakan berbagai macam sumber, berupa media cetak maupun media elektronik.

\section{Penilaian}

Bentuk penilaian yang digunakan yaitu Computer Assisted Testing (CAT), yaitu tes untuk mengukur kompetensi siwa secara kognitif. Dalam evaluasi ini setelah siswa mengerjakan, siswa akan langsung dapat mengetahui skor hasil belajar.

\section{Pengembangan produk (Develop)}

Tahap pengembangan produk ini adalah pembuatan atau produksi program multimedia pembelajaran patiseri yang mencakup langkahlangkah sebagai berikut:

\section{Membuat Flowchart (diagram alur)}

Flowchart adalah gambaran hubungan antar halaman dalam sebuah multimedia pembelajaran atau dapat juga diartikan sebagai simbol-simbol yang berisi langkah-langkah arus kontrol dari pelaksanaan suatu program. Tujuan dari pembuatan flow chart adalah untuk mempermudah penulisan program.

\section{Membuat Storyboard}

Story board adalah alur cerita yang menggambarkan tentang hal-hal yang terdapat dalam setiap slide dalam multimedia pembelajaran.

\section{Menyiapkan Materi dan Bahan Pendukung}

Pada tahap pengumpulan materi pembelajaran dilakukan dengan mengumpulkan bahan-bahan yang diperlukan berkaitan dengan pengembangan multimedia pembelajaran patiseri berupa: gambar-gambar, video, musik, menyusun naskah (teks) dan bahan pendukung lainnya.

\section{Memproduksi}

Proses pembuatan multimedia ini dilakukan dengan beberapa software diantaranya Macromedia Director $M X$ sebagai software utama dan beberapa software lain sebagai pendukung seperti Adobe Photoshop CS, Swiss, Ulead video 10 dan Microsoft Office 2007. Proses produksi berjalan kurang lebih 2 bulan dengan didahului pengumpulan materi dan bahan, dan pembuatan flowchart dan storyboard. Proses produksi berjalan dengan lancar berdasarkan storyboard yang sudah dibuat sebelumnya. Sebelum produk multimedia pembelajaran ini diuji kelayakannya oleh ahli materi dan ahli media, produk tersebut telah diujicobakan secara internal dengan komputer berbagai speck yang berbeda diantaranya: Pentium III dan pentium $I V$, Windows $\mathrm{XP}$, Windows 7 , dan windows 8 .

\section{Mengemas Produk Awal Dalam Bentuk CD (Compact Disk).}

Untuk mendapatkan Validasi produk sebelum diujicobakan terlebih dahulu produk awal dikemas ke dalam bentuk CD (Compact 
Tabel 3. Data Evaluasi Kelayakan Produk Ahli Materi dan Ahli Media

\begin{tabular}{cllcc}
\hline No. & Evaluasi & Aspek & Rerata Skor & Kategori \\
\hline 1. & Ahli Materi & $\begin{array}{l}\text { Materi } \\
\text { Isi Pembelajaran } \\
\text { Tampilan }\end{array}$ & 4,11 & Baik \\
2. Ahli Media & $\begin{array}{l}\text { Penyajian } \\
\text { Pemrograman }\end{array}$ & 3,84 & Baik \\
\hline
\end{tabular}

Disck), hal ini bertujuan untuk memudahkan pemeriksaan program oleh ahli materi dan ahli media serta untuk memudahkan pendistribusian. CD yang berisi program terlebih dahulu diperiksa dalam komputer untuk mengetahui apakah program dapat berjalan sesuai dengan yang iharapkan.

\section{Evaluasi dan Revisi}

Evaluasi dan revisi merupakan tahap untuk mengetahui kualitas dan kelayakan produk sebelum diujicobakan di lapangan. Evaluasi ini dilakukan dengan mengkonsultasikan produk awal kepada ahli materi dan ahli media untuk mendapatkan masukan, saran dan penilaian. Selanjutnya produk direvisi sesuai masukan dan saran. Setelah Produk direvisi, selanjutnya siap diujicobakan di lapangan. Setelah melalui tahap analisis dan revisi selanjutnya produk akan dikemas menjadi produk final dalam bentu CD Pembelajaran Patiseri.

\section{Evaluasi}

Data Evaluasi Kelayakan Produk oleh Ahli Materi.

Ahli Materi yang menjadi validator dalam penelitian ini adalah Dr. Siti Hamidah, Dosen pendidikan Teknik Boga Busana Fakultas Teknik dan dosen Pascasarjana Universitas Negeri Yogyakarta. Peneliti memilih beliau sebagai ahli materi karena beliau sangat kompeten di bidang Boga khususnya Patiseri. Data diperoleh dengan cara membawa produk awal multimedia pembelajaran dan print screen dengan disertai lembar evaluasi untuk ahli materi berupa kuisioner kepada ahli materi. Selanjutnya pengembang dengan ahli materi mendiskusikan kualitas produk multimedia pembelajaran tersebut. Ahli materi menilai dan memberikan masukan baik tertulis maupun lisan. Kuisioner berisi aspek materi pembelajaran, aspek isi dan aspek kebenaran materi pembelajaran dan isi. Hasil evaluasi berupa nilai untuk aspek kualitas materi pembelajaran dan isi dengan mengunakan skala likert 1 sampai 5, sedangkan aspek kebenaran materi pembelajaran dan isi berupa komentar dan saran perbaikan.

Data Evaluasi Kelayakan Produk oleh Ahli Media

Ahli media yang menjadi validator produk pengembangan multimedia pembelajaran ini adalah Bapak Dr. Zainur Rofiq. Beliau adalah dosen Teknik Mesin, Kepala multimedia Universitas Negeri Yogyakarta, dan Dosen Pascasarjana Universitas Negeri Yogyakarta. Alasan Pengembang memilih beliau sebagai ahli media karena beliau kompeten bidang multimedia dan media pembelajaran.

Data diperoleh dengan cara membawa produk awal multimedia pembelajaran yang sedang dikembangkan dan print screen dengan disertai lembar evaluasi berupa kuisioner kepada ahli media, kuisioner berisi angket aspek tampilan, aspek penyajian aspek pemrograman, kebenaran aspek tampilan, aspek penyajian dan aspek pemrograman, komentar dan saran. Selanjutnya ahli media dipersilakan untuk mencoba menggunakan produk multimedia dan mengisi kuisioner sesuai penilaian ahli media dan memberikan saran untuk perbaikan multimedia. Ahli media menjalankan multimedia sambil menunjukkan bagian-bagian yang perlu direvisi sedangkan pengembang membuat catatan revisi yang harus dibuat.

Dari data yang terlihat pada tabel 3 dapat dipresentasikan dalam bentuk grafik yang terdpat pada gambar 1 . 
Tabel 4. Data Evaluasi Produk Oleh Siswa

\begin{tabular}{cllcc}
\hline No. & Evaluasi & Aspek & Rerata Skor & Kategori \\
\hline 1. & Uji Coba Kelompok & Pembelajaran & & \\
& kecil & $\begin{array}{l}\text { Materi } \\
\text { Media }\end{array}$ & 4,39 & Sangat Baik \\
2. & Uji Coba Lapanagan & $\begin{array}{l}\text { Pembelajaran } \\
\text { Materi }\end{array}$ & & \\
& & Media & 4,49 & Sangat Baik \\
\hline
\end{tabular}

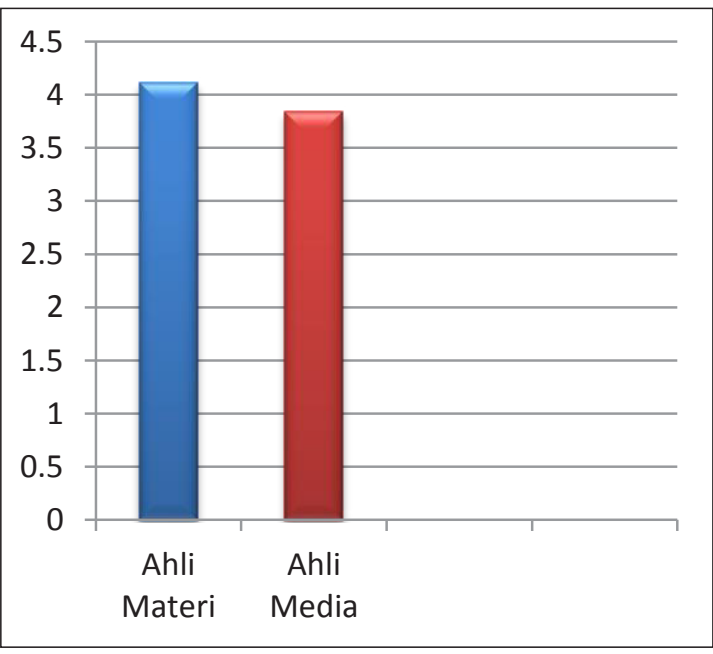

Gambar 1. Diagram Evaluasi Kelayakan Produk oleh Ahli Materi dan Ahli Media

Data Evaluasi Siswa Pada Uji Coba Kelompok Kecil dan Uji Coba Lapangan

Setelah produk multimedia melalui evaluasi dan revisi tahap I oleh ahli materi dan ahli media, kemudian produk diujicobakan kepada siswa. Uji coba dilaksanakan dalam sekala kecil ini dengan melibatkan sembilan siswa, terdiri dari tiga siswa berasal dari kelompok atas, tiga siswa dari kelompok sedang dan tiga siswa dari kelompok bawah. Uji Coba ini disebut uji coba kelompok kecil. Uji coba ini dilaksanakan di lab komputer di SMKN 4 Surakarta pada tanggal 22 Juli 2013, dengan membagikan CD Pembelajaran patiseri kepada 9 siswa tingkat XI Patiseri yang belum pernah mendapatkan materi pelajaran Standart Kompetensi Mengolah Kue Pastry Kontinental untuk mencoba produk multimedia pembelajaran patiseri dan selanjutnya diminta mengisi angket secara terpisah.
Untuk siswa kelompok besar, data Uji Coba lapangan diperoleh dari subyek penelitian sejumlah 27 siswa tingkat XI Patiseri SMKN 4 Surakarta untuk menguji kualitas produk multimedia yang lebih mendalam dengan setting lingkungan belajar seperti situasi pembelajaran patiseri pada umumnya dengan multimedia. Data diambil pada tanggal 25 Juli 2013 bertempat di Lab Komputer dilanjutkan ke Lab. Dapur Patiseri SMK N Surakarta.

Dari data tabel 4 dapat dipresentasikan dalam bentuk gambar yang dapat dilihat pada gambar 2.

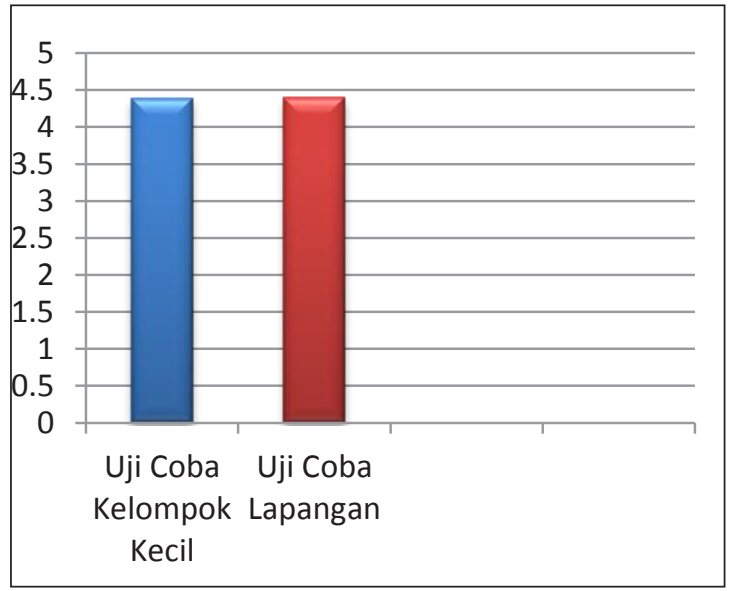

Gambar 2. Diagram Evaluasi Produk Oleh Siswa

Data Hasil pre-test dan post- test

Salah satu cara untuk mengetahui efektifitas produk multimedia adalah dengan cara membandingkan antara nilai tes awal (pretes t)dengan nilai tes akhir (post-test). Tes awal dan tes akhir dilakukan dengan 27 responden. Pada uji coba lapangan diawali dengan pretest dan diakhiri dengan post-test. Soal yang digunakan untuk pre-tes dan post-test adalah 
Tabel 5. Perbandingan Skor Pre-test dan Posttes

\begin{tabular}{llcccc}
\hline No. & Data Nilai & Pretest & Posttest & IndekGain & Kriteria \\
\hline 1. & Nilai minimal & 45 & 70 & & \\
2. & Nilai maksimal & 80 & 100 & & \\
3. & Nilai Total & 1705 & 2405 & 0,72 & Tinggi \\
4 & Rata-rata & 63,15 & 89,07 & & \\
\hline
\end{tabular}

sama, jenis soal pilihan ganda jumlah 20 butir soal. Nilai KKM untuk Kompetensi Mengolah Kue Pastry Kontinental adalah 78, dengan perolehan skor hasil pre-test dan posttest dapat disajikan dalam bentuk tabel sebagai berikut:

Dari data tabel 5 skor pre-test dan post-test di atas dapat dipresentasikan ke dalam grafik gambar 3.

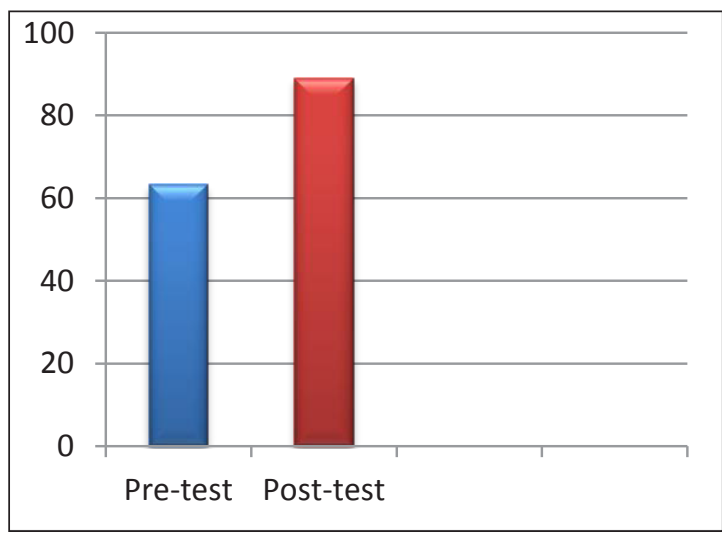

Gambar 3. Nilai Perbandingan Skor Pre-test dan Post-test

Analisis Hasil Uji Coba dan Pembahasan

a. Analisis Data Penilaian Ahli Materi dan Ahli Media

Secara keseluruhan dari kedua aspek penilaian ahli materi meliputi aspek materi pembelajaran dan aspek isi pembelajaran memperoleh rata-rata skor sebesar 4,11 nilai "B" termasuk kriteria "Baik". sehingga dapat disimpulkan bahwa produk awal multimedia pembelajaran yang dikembangkan ini dapat digunakan untuk ujicoba sesuai saran.

Dari sisi penilaian ahli media yang meliputi aspek tampilan, aspek penyajian dan aspek pemrograman memperoleh rata-rata skor sebesar 3,84 nilai "B" termasuk kriteria "Baik". sehingga dapat disimpulkan bahwa produk awal multimedia pembelajaran yang dikembangkan ini dapat digunakan untuk ujicoba sesuai saran.

Selain penilaian ahli materi dan media juga diberikan penilaian berupa informasi bagian yang salah, jenis kesalahan, saran, komentar dan masukan untuk revisi atau perbaikan kualitas produk multimedia yang dikembangkan. Penilaian berupa informasi bagian yang salah, jenis kesalahan, saran, komentar dan masukan selanjutnya dianalisis untuk slanjutnya dilakukan revisi atau perbaikan produk sesuai saran yang relevan.

b. Analisis Data Hasil Uji Coba Kelompok Kecil dan Uji Coba Lapangan

Secara keseluruhan dari ketiga aspek penilaian kelompok kecil yang meliputi aspek pembelajaran, aspek materi dan aspek media memperoleh rata-rata skor sebesar 4,39 nilai "A" termasuk kriteria "Sangat Baik", sehingga dapat disimpulkan bahwa multimedia pembelajaran yang dikembangkan sesuai hasil ujicoba kelompok kecil "sangat layak" digunakan untuk media pembelajaran patiseri dalam uji coba lapangan.

Ketiga aspek penilaian dari uji coba kelompok besar yang meliputi aspek pembelajaran, aspek materi dan aspek media pada uji coba lapangan memperoleh rata-rata skor sebesar 4,49 nilai " $A$ " termasuk kriteria "Sangat Baik", sehingga dapat disimpulkan bahwa multimedia pembelajaran yang dikembangkan sesuai hasil ujicoba kelompok kecil "sangat layak" digunakan untuk media pembelajaran patiseri.

Analisis Perbandingan skor Pretest dan Posttest

Berdasarkan data hasil pretest dan posttes dapat diketahui bahwa nilai rata-rata hasil data pretest adalah 63,15 , Jumlah siswa tuntas 3 orang, siswa belum tuntas 24 oang, persentasi 
ketuntasan secara klasikal $11,11 \%$ sedangkan dari data posttes diketahui bahwa nilai rata-rata postest 89,07 , jumlah siswa tuntas 25 orang, jumlah siswa belum tuntas 2 orang, persentasi ketuntasan secara klasikal 92,59\%.

Berdasarkan data tabel 39, dapat diketahui Indeks Gain sebesar 0,72 setelah dikonsultasikan dengan tabel 2 interpretasi $N$-Gain pada halaman 7 termasuk dalam kriteria tinggi. Daripenjelasan di atas dapat disimpulkan bahwa produk multimedia pembelajaran patiseri ini efektif untuk meningkatkan hasil belajar pada Standart Kompetensi Pengolahan Kue Pastry Kontinental, dan dapat digunakan untuk pembelajaran patiseri tingkat XI SMK.

\section{Revisi}

\section{Revisi Produk Ahli Materi}

Berdasarkan analisis data validasi oleh ahli materi, pengembang melakukan beberapa revisi berdasarkan saran perbaikan. Revisi yang dilakukan berdasarkan saran dari ahli materi adalah menambahkan identitas lembaga lengkap dan pengembang pada tampilan pendahuluan, menambahkan materi penjelasan tahapan menghias kue.

\section{Revisi Produk Ahli Media}

Berdasarkan analisi data validasi oleh ahli media, pengembang melakukan beberapa revisi berdasarkan saran perbaikan. Revisi yang dilakukan berdasarkan saran dari ahli materi adalah sebagai berikut: (1) menambahkan tombol volume agar volume dapat dikontrol oleh pengguna; (2) pada sub materi tulisan (font) terlalu kecil sehingga perlu diperbesar dan dilengkapi tombol untuk maju, sehingga lebih memudahkan pengguna dalam memanfaatkan multimedia; (3) pada rangkuman diperbaiki secara redaksionalnya agar kalimat lebih runtut dan lebih baik.

Revisi Produk Pada Uji Coba kelompok kecil dan Uji Coba Lapangan

Hasil penilaian kualitas produk dari siswa pada uji coba kelompok kecil dan uji coba lapangan memberikan penilaian "sangat baik" dan memberikan tanggapan positif dan sangat senang terhadap pembelajaran degan multimedia ini. Hasil penilaian pada ujicoba kelompok kecil tidak ada revisi, namun demikian siswa memberikan saran dan masukan seperti: perbanyak gambar-gambar dan vidio. Saran untuk perbanyak gambar dipenuhi dengan menambahkan gambar background pada slide, tetapi saran untuk menambahkan vidio tidak dapat dipenuhi mengingat kapasitas CD terbatas, sedangkan produk akhir dikemas dalam bentuk $\mathrm{CD}$, sehingga penambahan video tidak mungkin dilakukan.

\section{Produk Akhir}

Tahap akhir dari pengembangan multimedia pembelajaran patiseri ini adalah penyalinan program yang sudah final ke dalam bentuk CD (Compact Disck) hal ini bertujuan untuk untuk mempermudah pendistribusian.

\section{Kajian Produk Akhir}

Pengembangan multimedia pembelajaran patiseri ini menggunakan program macromedia director $M X$ sebagai software utama. Standar kompetensi yang dimediakan yaitu mengolah kue pastry kontinental, standar kompetensi membuat bahan pengisi dan bahan penutup kue dengan butter cream, royal icing dan coklat. Multimedia pembelajaran patiseri yang dikembangkan ini telah melalui tahapantahapan pengembangan, yang meliputi: tahap analisis kebutuhan, tahap pengembangan desain pembelajaran, tahap pengembangan produk, tahap evaluasi produk dan tahap produk akhir sehingga menghasilkan produk multimedia pembelajaran yang layak ditinjau dari aspek tampilan, aspek penyajian, aspek pemrograman serta aspek materi pembelajaran dan isi pembelajaran.

Berdasarkan saran dan masukan dari ahli materi dan ahli media, serta responden dalam uji coba kelompok kecil dan dan uji coba lapangan, maka telah dilakukan perbaikan dan revisi pada produk multimedia ini. Hasil analisis pada uji coba lapangan menunjukkan bahwa: (1) hasil penilaian siswa terhadap aspek pembelajaran memperoleh skor ratarata 4.47 nilai " $A$ " sehingga masuk dalam kriteria "Sangat Baik"; (2) hasil penilaian siswa terhadap aspek materi memperoleh skor rata-rata 4,50, nilai "A" masuk dalam kriteria "Sangat Baik"; (3) hasil penilaian siswa terhadap aspek media memperoleh skor rata-rata 4,52, nilai " $A$ " masuk dalam kriteria 
"Sangat Baik"; (4) hasil pretest dan posttes pada untuk mengetahui keefektifan produk diketahui bahwa dengan membandingkan skor pretes dan postest diketahui $\mathrm{N}$-Gain skor sebesar 0,72 setelah dikonsultasikan dengan tabel interpretasi $\mathrm{N}$-Gain termasuk dalam kriteria tinggi, sehingga dapat disimpulkan bahwa hasil belajar siswa meningkat setelah memanfaatkan produk multimedia pembelajaran patiseri.

Hasil observasi selama uji coba lapangan berlangsung, responden memperlihatkan antusiasme yang tinggi dan keseriusan dan ketertarikan yang positif terhadap multimedia pembelajaran ini. Sebagian besar dari siswa menunjukkan ketertarikan dan ketekunan selama proses uji coba pembelajaran dengan multimedia pembelajaran berlangsung. Siswa terlihat antusias mengikuti setiap bagian pembelajaran, terutama pada bagian evaluasi dan mengamati vidio menghias cake. Memasuki kegiatan latihan evaluasi tertulis, siswa antusias untuk mendapatkan skor yang baik. Ketekunan juga terlihat pada saat siswa membuat perencanaan tertulis untuk praktik membuat cake decorations.

Tanggapan siswa tentang kelebihan produk multimedia dapat dirangkum sebagai berikut: (1) produk multimedia pembelajaran patiseri ini sangat membantu siswa untuk membantu meningkatkan pemahaman materi pada kompetensi dasar mengolah kue pastry kontinental, standar kompetensi membuat bahan pengisi dan bahan penutup kue dengan butter cream, royal icing dan coklat; (2) materi yang disediakan menarik ditambah video menghias kue dengan butter cream sangat bagus dan sangat membantu untuk menuangkan ideide saat praktik; (3) belajar dengan multimedia interaktif sangat menyenangkan karena siswa bebas memilih materi yang ingin dipelajari.

Selain tanggapan siswa tentang kelebihan produk tersebut di atas juga dirangkum beberapa kekurangan dari produk multimedia ini yang terangkum sebagai berikut: (1) latihan soal masih dianggap kurang banyak dan kurang variasi jenis soal, sehingga masih perlu ditambah; (2) loading untuk video agak panjang, sehingga perlu diperpendek; (3) gambar-gambar dan vidio masih dianggap kurang, sehingga perlu diperbanyak.
Berdasarkan hasil uji-coba yang dipaparkan di atas, maka dapat disimpulkan bahwa multimedia pembelajaran patiseri yang dikembangkan dalam bentuk CD pembelajaran ini mendapatkan respon yang baik di lapangan dan layak digunakan dalam pembelajaran patiseri di tingkat XI SMK.

\section{SIMPULAN DAN SARAN}

\section{Simpulan}

Produk yang dihasilkan berupa multimedia pembelajaran Patiseri dalam bentuk keping $C D$ (Compact Disk) diselesaikan melalui 5 tahap, yaitu: (1) analisis kebutuhan; (2) perencanaan pengembangan produk; (3) pengembangan produk; (4) evaluasi produk, dan (5) pengemasan produk akhir dalam bentuk $\mathrm{CD}$.

Kualitas kelayakan media berdasarkan penilaian ahli materi terhadap produk multimedia pembelajaran patiseri secara keseluruhan memenuhi kriteria "baik" skor rata-rata yang diperoleh sebesar 4,11 . Dengan demikian produk multimedia pembelajaran patiseri ini dapat dikatakan "layak" digunakan untuk media pembelajaran ditinjau dari aspek pembelajaran dan isi.

Kualitas kelayakan media berdasarkan penilaian ahli media terhadap produk multimedia pembelajaran patiseri secara keseluruhan memenuhi kriteria "baik", skor rata-rata yang diperoleh sebesar 3,84 . Dengan demikian produk multimedia pembelajaran patiseri ini dapat dikatakan "layak" digunakan untuk media pembelajaran ditinjau dari aspek tampilan, penyajian, dan pemrograman.

Penilaian siswa terhadap kualitas produk multimedia pembelajaran patiseri ini secara keseluruhan memenuhi kriteria "sangat baik" dengan skor rata-rata yang diperoleh sebesar 4,49. Dengan demikian produk multimedia pembelajaran patiseri ini dapat dikatakan "sangat layak" digunakan untuk media pembelajaran ditinjau dari aspek pembelajaran, aspek materi, dan media.

Produk multimedia pembelajaran patiseri ini efektif untuk meningkatkan hasil belajar siswa, hal ini dapat dilihat dari selisih perbedaan hasil ( $N$-Gain) skor yang diperoleh siswa pada 
saat pretest dan potstest. Peningkatan ratarata $N$-Gain skor nilai pretest dan posttest sebesar 0,72 setelah dikonsultasikan dengan tabel interpretasi $\mathrm{N}$-Gain termasuk dalam kriteria tinggi, sehingga dari penjelasan di atas dapat disimpulkan bahwa produk multimedia pembelajaran patiseri ini efektif untuk meningkatkan hasil belajar pada Standart Kompetensi Pengolahan Kue Pastry Kontinental, dan dapat digunakan untuk pembelajaran siswa SMK program kehlian Patiseri.

\section{Saran}

Dengan adanya multimedia pembelajaran patiseri berupa $C D$ disarankan agar guru memanfaatkan multimedia pembelajaran ini sebagai media dalam pembelajaran patiseri, karena dengan media $\mathrm{CD}$ pembelajaran patiseri ini pembelajaran menjadi berbeda dari biasanya dimana pembelajaran menjadi lebih menarik, menyenangkan mengurangi kejenuhan dan siswa menjadi lebih kreatif dalam menuangkan ide-ide terutama dalm praktik menghias kue.

Untuk menghemat biaya penggandaan $\mathrm{CD}$, multimedia pembelajaran patiseri ini dapat disimpan di hardisk komputer sekolah. Agar pembelajaran tidak terbatas hanya di sekolah, sekaligus untuk memudahkan siswa dalam mempelajari materi ini lebih lanjut, siswa diperbolehkan meng-coppy file ini dan menyimpannya di flash disk. sehingga dapat digunakan untuk pembelajaran secara mandiri di rumah, ataupun di rental komputer bagi siswa yang tidak memiliki laptop atau computer. Penyimpanan software multimedia pembelajaran di flash disk juga untuk mengantisipasi apabila laptop yang dimiliki siswa tidak memiliki fasilitas $C D / D V D$ Room.

\section{DAFTAR PUSTAKA}

Arsyad, A. (2006). Media Pembelajaran. Jakarta: Rajawali Press.

Dick, W, Carey, L. \& Carey, J.O. (2005). The systematic design of instructions. $\left(6^{\text {th }}\right.$ ed.) NY: Pearson.

Depdiknas. (2003) UU RI No.20, Tahun 2003, tentang Sistem Pendidikan Nasional.

(2006). Peraturan Menteri Pendidikan Nasional Republik Indonesia Nomor 22., Tahun 2006, tentang Standar Isi.

Gall, M.D., et al. (2003). Educational research: an introductions ( $7^{\text {th }}$ ed.) Boston: Pearson Education, Inc.

Hake, R.R. (1998). Interactive engage-ment methods in introductory mechanicscourses. Departement of Physics, Indiana University, Bloomingtoon. Diambil pada tanggal 2 Mei 2013, dari http://www.iub.edu/ iubphys/

Miarso, Y.H.(2004). Menyemai benih teknologi pendidikan. Jakarta : PT Prenada media.

Sugiyono. (2011). Metode penelitian pendidikan. Bandung: Penerbit Alfabeta.

Sukardjo. (2010). Evaluasi pembelajaran. Diklat matakuliah evaluasi pembelajaran. Prodi Teknologi Pembelajaran Program Pascasarjana Universitas Negeri Yogyakarta. Tidak diterbitkan. 